\title{
How 'Improved triage and emergency care for children reduces inpatient mortality in a resource-constrained setting' changed my life
}

\author{
Georgina Ann Phillips, MBBS, FACEM
}

Emergency physician, St. Vincent's Hospital, Melbourne PhD Scholar, Monash University, Melbourne, Australia

Email: drgeorgina@gmail.com

How do you know that what you do, and what you advocate for, makes a difference? How do you know that a triage system, or a resuscitation room actually saves the lives as you assume these things should?

In my two decades of work in global Emergency Care (EC) around the Pacific and in South East Asia, these questions have plagued me. Under scrutiny from hostile or ignorant aid donors, the evidence of the value of investing in EC seems weak when compared with the mountain of public health research from developing countries. "Hospitals are luxuries", I was once told by a senior health official within the Australian aid program. How does one even begin to address this level of understanding and is EC really the solution to poor health outcomes in resource-constrained settings?

In their eloquent 2006 paper ${ }^{i}$ Elizabeth Molyneux and colleagues make a simple but compelling case. I discovered the paper in $\mathbf{2 0 0 9}$ while preparing for my sabbatical in Papua New Guinea (PNG). Molyneux's research was a revelation and became a foundation upon which I would build my own global EC practice and research.

Without fanfare, Molyneux outlines the problems faced by her busy children's clinic in the public tertiary care hospital in Blantyre, Malawi. They are problems familiar to anyone who has engaged with EC in developing countries: too few and untrained staff; no space and inadequate equipment for resuscitation; overcrowding and no system to prioritise children by need; poor cooperation within the hospital; and low staff morale. I've done emergency department needs-analyses in Timor-Leste, PNG, Kiribati and the Solomon Islands. In each place the same themes emerge. The solutions are complex and take time, yet Molyneux and her colleagues outline the steps taken and in doing so, define the components of an EC system with clarity and simplicity.

Aid donors often assume EC is expensive and high-technology, perhaps poisoned by popular television shows. Molyneux demonstrates how effective improvement in EC can happen with small but sustained changes and within substantial resource constraints. Over four years, her team worked collaboratively to train staff in triage and EC, to redesign their physical environment and secure basic equipment, to rearrange patient flow and introduce

This is the author manuscript accepted for publication and has undergone full peer review but has not been through the copyediting, typesetting, pagination and proofreading process, which may lead to differences between this version and the Version of Record. Please cite this article as doi: 10.1111/1742-6723.13263

This article is protected by copyright. All rights reserved. 
a new triage system, increase staffing numbers, improve relations with inpatient teams and introduce regular monitoring of workload. She transformed a chaotic, unstructured clinic into what we all recognise as a modern-day ED. Most importantly, Molyneux had some data to show that these changes saved lives: inpatient mortality reduced; and deaths within 24 hours of arrival fell dramatically.

No other research I know of demonstrates so neatly how introducing a hospital EC system improves outcomes. Doctors focus on quantitative results: percentages of lives saved. But each time I read this paper, the process and qualitative results are compelling. Molyneux applied an iterative process of collaborative change in partnership with all the stakeholders. She describes team-building, consistent nurse-led triage, improved cooperation and better morale. Her simple 3-scale triage system ('ETAT' Emergency Triage, Assessment and Treatment) is the standard for paediatric triage around the globe.

I love re-reading this paper. The clear, fresh writing from a strong woman clinician, researcher, advocate and global health leader speaks with great authority. Molyneux concludes her paper with an inspiring message: it takes enthusiastic leadership, team-spirit, commitment and determination to initiate and sustain change.

\footnotetext{
' Molyneux E, Ahmad S, Robertson A. Improved triage and emergency care for children reduces inpatient mortality in a resource constrained setting. Bull World Health Org 2006;84:314-319
} 


\section{University Library}

\section{- M M I N E R VA A gateway to Melbourne's research publications}

Minerva Access is the Institutional Repository of The University of Melbourne

Author/s:

Phillips, GA

Title:

How 'Improved triage and emergency care for children reduces inpatient mortality in a resource-constrained setting' changed my life

Date:

2019-04-01

Citation:

Phillips, G. A. (2019). How 'Improved triage and emergency care for children reduces inpatient mortality in a resource-constrained setting' changed my life. EMERGENCY MEDICINE AUSTRALASIA, 31 (2), pp.287-287. https://doi.org/10.1111/1742-6723.13263.

Persistent Link:

http://hdl.handle.net/11343/285473 